\title{
Zona pellucida birefringence evaluation
}

\section{Avaliação da birrefringência da zona pelúcida}

\author{
Bianca Casagrande Kreuscher, Vinícius Bonato da Rosa ${ }^{1}$, José Augusto Lucca Neto ${ }^{1}$, Alessandro \\ Schuffner ${ }^{1}$ \\ ${ }^{1}$ Centro de Reprodução Humana
}

\section{RESUMO}

Objetivo: Este trabalho teve como objetivo fazer uma revisão bibliográfica dos trabalhos que abrangem assuntos sobre a birrefringência da zona pelúcida.

Materiais e Métodos: Levantamento bibliográfico em revistas científicas tais como: Fertility Sterility; Human Reproduction, Reproduction BioMedicine Online; Revista Brasileira de Análises Clínicas; Revista Brasileira de Ginecologia e Obstetrícia; o manual de procedimentos da Red Latinoamericana de Reproducción Asistida; entre outros. A variação de data de busca nos artigos selecionados foi de dez anos (2001 a 2011).

Revisão de Literatura: Os esforços para identificar parâmetros confiáveis para a avaliação da qualidade do oócito são uma prioridade para a execução da técnica de Reproduçao Humana Assistida. A birrefringência da zona pelúcida está sendo estudada para identificar o oócito com o maior potencial de desenvolvimento para se tornar um embrião com maiores chances de desenvolvimento, sendo que a camada interna da zona pelúcida pode ser proposta como marcador de qualidade do oócito.

Discussão: Algumas pesquisas concluíram que oócitos com alta birrefringência tem maiores chances de fertilização e que a birrefringência da zona pelúcida diminu à medida que as fases de maturação oocitária ocorrem. Conclusão: Esta revisão mostrou um possível potencial benéfico da luz polarizada na avaliação da birrefringência da zona pelúcida, podendo portando ser utilizada como preditor da qualidade oocitária.

Palavras-chave: infertilidade, FIV, ICSI, birrefringência, zona pelúcida.

\section{ABSTRACT}

Objective: This study aimed review papers that cover the birefringence of the zona pellucida.

Materials and Methods: Bibliographic in scientific journals such as Fertility Sterility, Human Reproduction, Reproductive BioMedicine Online, Revista Brasileira de Análises Clínicas, Revista Brasileira de Ginecologia e Obstetrícia, the manual of procedures of the RedLatinoamericana de Reproducción Asistida, among others. The change of date search in the selected articles was ten years (2001-2011).

Literature Review: Efforts to identify reliable parameters for the assessment of oocyte quality is a priority for the implementation of the Assisted Human Reproduction techniques. The birefringence of the zona pellucida is being studied to identify the oocyte with the greatest development potential to become an embryo with the greatest chances of development, and the inner layer is the one that can be proposed as a marker of oocyte quality.

Discussion: Some oocytes researchers concluded that high birefringence has a greater chance of fertilization and the birefringence of the zona pellucida decreases as the phases of oocyte maturation occur.

Conclusion: This review showed a possible potential benefit of polarized light in the evaluation of the bire- fringence of the zona pellucida, and therefore may be used as predictor of oocyte quality.

Keywords: infertility, IVF, ICSI, birefringence, zona pellucida.

\section{INTRODUCTION}

Hormonal and uterine tube problems are the main factors associated to infertility in women. The PCOS is the most common cause of non ovulatory infertility. Aging is another factor that can lead to infertility in both men and women. In women, the oocyte quality decreases with aging which leads to a increased risk of aneuploidies, which can result in the absence of pregnancy, cases of abortions, or even children with deficiencies acquired during conception or early embryonic development (Kussler \& Coitinho, 2008).

Among the techniques used in assisted reproduction, the main ones are intrauterine insemination (IUI), in vitro fertilization (IVF) and intracytoplasmic sperm injection (ICSI) (Kussler \& Coitinho, 2008). According to Brandes et al (2011), there is a tendency to decrease the number of transferred embryos post IVF or ICSI treatments. Several countries, including Brazil, already have restricted rules that regulate the number of transferred embryos. These worldwide regulations implies the search for a better oocyte selection and consequently better quality embryos with higher potential to lead to a pregnancy (Jelinkova et al., 2008).

The polarized light microscopy came as important tool to help the method of oocyte selection. This technique allows the assessment the birefringence of the zona pellucida (ZP) through a of polarized light beam (Montag et al., 2008a; Borges et al., 2010). The image of the zona pellucida has been shown to be a good predictor factor of oocyte viability (Montag et al., 2008a; Borges et al., 2010).

In the preparation of this review, the following journals and manuals were used: Fertility Sterility; Human Reproduction, Reproduction BioMedicine Online; Brazilian Journal of Clinical Analysis (Revista Brasileira de Análises Clínicas); Brazilian journal of gynecology and Obstetrics (Revista Brasileira de Ginecologia e Obstetrícia); manual of procedures from the Latin American Assisted Reproductive Network (manual de procedimentos da Red Latinoamericana de Reproducción Asistida); among others.

The search criteria included papers that had a main focus on the use of polarized light to visualize the meiotic spindle, as well as papers that mentioned zona pellucida score. The search was restricted to papers published between 1990 and 2011.

\section{MATERIAL E METHOD}

In the preparation of this review, the following journals and manuals were used: Fertility Sterility; Human Reproduction, Reproduction BioMedicine Online; Brazilian Journal of Clinical Analysis (Revista Brasileira de Análises Clínicas); Brazilian journal of gynecology and 
Obstetrics (Revista Brasileira de Ginecologia e Obstetrícia); manual of procedures from the Latin American Assisted Reproductive Network (manual de procedimentos da Red Latinoamericana de Reproducción Asistida); among others.

The search criteria included papers that had a main focus on the use of polarized light to visualize the meiotic spindle, as well as papers that mentioned zona pellucida score. The search was restricted to papers published between 1990 and 2011.

\section{LITERATURE REVIEW}

\section{OOCYTE CLASSIFICATION}

Morphology is used to assess the quality and select better oocytes (Munné et al., 2006) and may potentially influence embryo implantation and development. Some morphological changes have been frequently observed such as color of the zona pellucida and shape of oocytes (Borges et al., 2009a).

The observation of embryonic development may supply more precise information about the embryo (Rienzi et al., 2010). The assessment of morphology of the recovered oocyte during IVF is superficial and the evaluation of the inseminated oocytes is restricted to the presence of cumulus cells (Rienzi et al., 2010).

When ICSI is performed, a rapid assessment through an inverted microscope is also performed after denudation, including cytoplasm, perivitelline space and zona pellucida (ZP) evaluation. These observations supply basic information about the stage of meiotic division and the quality of the oocytes such as degenerative signs of the cytoplasm, polar body (PB) or ZP.

Oocyte classification can be performed to assess cytoplasmic defects such as granules, vacuoles, polar body fragments, abnormal shape among others. Such classification can also be conducted to establish the stage of oocytes maturation: prophase I, metaphase I and metaphase II. The oocyte morphology was positively correlated to embryonic development and pregnancy rates (Ahumada et al., 2006).

Women older than forty present a higher frequency of oocyte abnormalities, such as polar body fragmentation, increased perivitelline space and changes in the zona pellucida (Ahumada et al., 2006). The introduction of ICSI allowed the correlation between oocyte morphology with fertilization, cleavage rates and embryonic development. As a result, different views about this correlation between oocyte morphology and fertilization outcome were publicized. However, there is no consensus yet if oocyte morphology allows the prediction of fertilization outcome. While some groups agree that certain aspects of oocyte morphology are associated to better or worse results, others believe that oocyte morphology does not interfere on fertilization, embryo quality and pregnancy rates following ICSI (Aggelis et.al., 2006).

According to Rienzi et al., 2010, oocyte quality is a result not only from the nuclear and mitochondrial genome, but also from the microenvironment supplied by the ovary and the preovulatory follicle, which can modify the transcription and translation of the germ cells.

In order to human MII oocytes be considered as good quality, it is necessary to have a clear and slightly granular cytoplasm, without inclusions, small perivitelline space and with a translucent and uncolored ZP (Rienzi et al., 2008; Setti et al., 2011). However, more than half of the recovered oocytes have at least one morphological abnormality (Ebner et al., 2010; Setti et al., 2011). These morphological abnormality are more common classified as intracytoplasmic features or cytoplasm increase, granularity and presence of cytoplasmic inclusions (Figueira et al., 2009; Setti et al., 2011).

ROLE OF ZONA PELLUCIDA DURING FERTILIZATION The zona pellucida is a species-specific membrane that surrounds the oocyte (Hardy e Garbers, 1994), and it is composed of filaments organized in layers in differing orientation. The first interaction between the sperm cell and oocyte occurs at the ZP and the result of this interaction is the beginning of acrosome reaction. The interaction between gametes triggers physiological events that are involved with the recognition of the species, adhesion and fusion between them (Borges JR et al., 2009b; Ben-Yosef \& Shalgi et al., 2001).

According to Ebner et al., 2010, the ZP may function as an ideal marker of folliculogenesis and/or oocyte maturation. The ZP glycoproteins seems to be coordinately secreted by the oocyte during folliculogenesis (Shen et al., 2005). There is also evidence that granulosa cells can contribute to the stage dependent of ZP protein expression during folliculogenesis (Shen et al., 2005). The ZP is a physical barrier that protects the oocyte and pre-embryos from antigens during the pre-implantation period. Receptors at the ZP are able to recognize the sperm cells on the surface of the oocyte and these may inhibit the association between them impeding fertilization (Liu et al., 2004).

\section{BIREFRIGENCE OF THE ZONA PELLUCIDA}

The use of polarized light microscopy allows the visualization of three different layers of this extracellular matrix surrounding the oocyte (Shen et al., 2005) which represents a new predictive factor its quality (Montag et al., 2008a; Borges et al., 2010). The birefringence of the inner layer of the ZP has been used to identify the oocyte with higher potential to progress into an embryo with increased chances of development (Jelinkova et al., 2008). For this assessment, a totally automated system is used which analyze the intensity and homogeneity of the birefringence (Ebner et al., 2010). The image of the zona pellucida has been shown to be a good predicted factor of embryo viability, however, this assessment should be performed during the oocyte stage and it is not recommended with prolonged culture due to an increase in birefringence zone (Montag et al., 2008b). The polarized light microscopy is a non invasive method and this allows the visualization without any change in the viability and integrity of the oocyte (Jelinkova et al., 2008; Molinari et al., 2010).

Studies performed with PolScope demonstrated that each layer of the ZP presents a different pattern related to the birefringence. The inner layer showed the highest birefringence with radially arranged filaments and the outer layer had a moderate birefringence due to the tangential orientation of its filaments which decreased the light to a lower degree. The medium layer presents birefringence due to irregular position of its filaments (Rama Raju et al., 2007; Silva et al., 1997).

Figures 1 and 2 demonstrate the differences between high birefringence (positive value +3.5 ) and low birefringence (negative value, $-8,7$ ). It is possible to observe that birefringence with positive values display better defined layers.

There are other tools to assess the birefringence of the ZP. These tools are based on the automatic detection of the birefringence of the inner layer (Montag et al., 2008b).

\section{DISCUSSION}

Several studies were and still are conducted to improve the process of IVF. This improve can be achieved throu$\mathrm{gh}$ the sperm cell selection according to their morphology as well as the oocyte selection which morphology and physiology aspects can be assessed by the birefringence of the ZP and the mitotic spindle.

In vitro mature oocytes recovered from control ovarian stimulation were assessed by birefringence (Braga et al., 2009). In this study, higher birefringence was associated with a significantly increased rate of oocyte fertilization. For oocytes in metaphase II (MII), the higher birefringence were strongly associated with high quality embryos. However, the birefringence of the ZP in immature oocytes had no effect on fertilization. Similar results were not observed when assessment was perfor- 


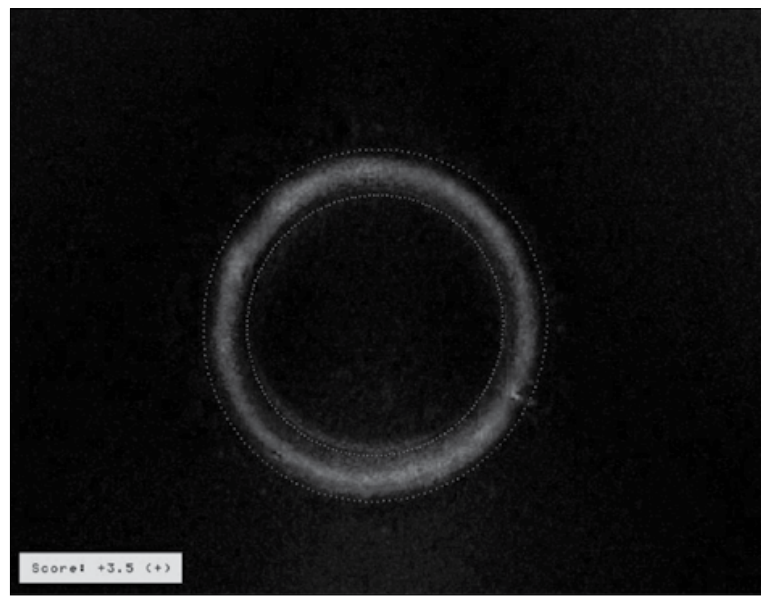

Figure 1. Birefringence of ZP with the Score +3.5. (Clinica Conceber - Human Reproduction Center)

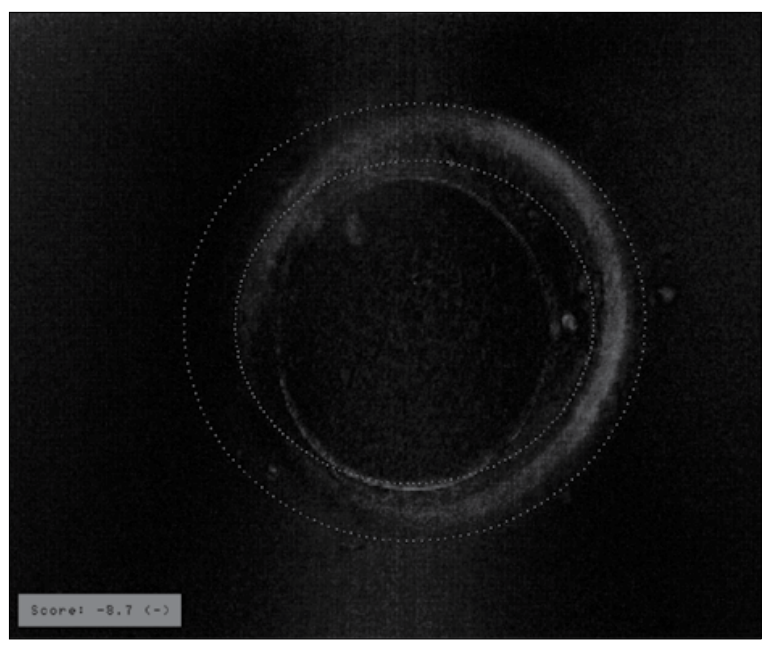

Figure 2. Birefringence of ZP with the Score -8.7. (Clinica Conceber - Human Reproduction Center)

med in spontaneous matured oocytes. Higher rates of fertilization in oocytes in prophase I (PI) and metaphase I (MI) with high birefringence was observed when compared to oocytes in MII. The amount of oocyte with high birefringence was greater in oocytes PI in relation to MI (Braga et al., 2009). The enlarged width of the inner layer was correlated with an increase in blastocyst rates (Rama Raju et al., 2007), higher embryo development and better pregnancy rates (Rienzi et al., 2010). Transfer of embryos with high birefringence of the zona pellucida inner layer showed better development on the day 3 , higher implantation, pregnancy and live born when compared to embryos derived from oocytes with low birefringence (Montag et al., 2008b; Braga et al., 2009)

\section{CONCLUSION}

To achieve success on the techniques used in reproductive medicine, several factors should be taken in consideration such as quality of sperm, oocyte and its components. The polarized light microscopy technique is used to assess the birefringence or the ZP which is considered by several investigators as the main component to evaluate oocyte quality (Rama Raju et al., 2007; Montag et al., 2008b).

Studies have been continuously conducted in attempt to identify germ cells characteristics that better define embryo quality (Rienzi et al., 2010). Some of these studies suggested that oocytes with high birefringence have higher fertilization rates, especially those with high birefringence in PI and MI stage when compared to MII oocytes. Therefore, this review showed a potential advantage in the use of polarized light on the assessment of the ZP birefringence and its use as predictive of oocyte quality (Montag et al., 2008b). More studies are necessary to confirm the relationship between ZP birefringence and pregnant rates because of the conflicting results presented in this review.

\section{Corresponding Author}

Conceber - Centro de Reprodução Humana

Accredited Redlara centre

Av. República Argentina, $210 / 17^{\circ}$ andar

CEP: 80240-210 - Curitiba - PR

Tel.: (41) 3039-5556

E-mail: alessandro@clinicaconceber.com.br

\section{REFERENCES}

Ahumada A et al. Manual de procedimentos laboratório de reprodução assistida. Red Latinoamericana de Reproducción Asistida. 2006

AGGELIS A et al. Relationship between oocyte morphology and fertilization rate after ICSI. Rev. Bras. Ginecol. Obstet. 2006; 28:220-226.

Ben-Yosef D, Shalgi R. Oocyte activation: lessons from human infertility. Trends Mol Med. 2001; 7:163-169.

Borges JR E et al. Zona pellucida birefringence score and meiotic spindle visualization in relation to embryo development and ICSI outcomes. Reprod. BioMed. Online. 2009a; 18:681-686.

Borges JR E et al. Outcome of ICSI using zona pellucidabound spermatozoa and conventionally selected spermatozoa. Reprod. BioMed. Online. 2009b; 19:802-807.

Borges JR E et al. Zona pellucida birefringence in in vivo and in vitro matured oocytes. Fertil. Steril. 2010; 94: 2050-2053.

Braga Dpaf et al. Prognostic value of meiotic spindle imaging on fertilization rate and embryo development in in vitromatured human oocytes. Fert. Steril. 2009; 90:429-433.

Brandes $M$ et al. Is the fertility treatment itself a risk factor for early pregnancy loss? Reprod. BioMed. Online. 2011; 22:192-199.

Ebner $\mathrm{T}$ et al. Automatic user-independent zona pellucida imaging at the oocyte stage allows for the prediction of preimplantation development. Fertil. Steril. 2010; 94:913-920.

Figueira RCS et al. Metaphase II human oocyte morphology: contributing factors and effects on fertilization potential and embryo developmental ability in ICSI cycles. Fertil. Steril. 2009; 94:1115-1117.

Hardy DM, Garbers DL. Species-specific Binding of Sperm Proteins to the extracellular matrix (zona pellucida) of the egg. JBC. 1994.

Jelinkova $L$ et al. The prognostic value of automatic scoring of zona pellucida birefringence in correlation with embryo morphology at day 5. Fertil Steril. 2008; 90:S392.

Kussler AP, Coitinho AS. Técnicas de reprodução assistida no tratamento da infertilidade. Revista Brasileira de Análises Clínicas. 2008; 40:313-315.

Liu DY et al. Low proportions of sperm can bind to the zona pellucida of human oocytes. Hum. Reprod. 2003; 18: 2382-2389.

Liu DY et al. Clinical application of sperm-oocyte interaction tests in in vitro fertilization-embryo transfer and intracytoplasmatic sperm injection programs. Fertil Steril. 2004; 82:1251-63.

Molinari E et al. Slow-freezing-induced changes of birefringent structures in human oocytes are related to responsiveness to ovulation induction. Reprod. BioMed. Online. 2010; 20:619-624. 
Montag M et al. Oocyte zona birefringence intensity is associated with embryonic implantation potential in ICSI cycles. Reprod. BioMed. Online. v.16, n.12, p. 239-244, 2008a.

Montag $\mathrm{M}$ et al. Oocyte assessment and embryo viability prediction: birefringence imaging. Reprod. BioMed. Online. 2008b; 17:454-460.

Munné $\mathrm{S}$ et al. Chromosome abnormalities and their relationship to morphology and development of human embryos. Reprod. BioMed. Online. 2006; 12:234-253.

Nogueira AA et al. Avaliação da concordância diagnóstica entre métodos não invasivos e endoscopia na investigação de infertilidade. Rev. Bras. Ginecol. Obstet. 2005; 27:401-406.

OMS. Organização Mundial da Saúde. 2010.

Pasqualotto FF et al. Investigação e reprodução assistida no tratamento da infertilidade masculina. Rev. Bras. Ginecol. Obstet. 2007; 29:103-112.

Pelletier C, Keefe DL, Trimarchi JR. Noninvasive polarized light microscopy quantitatively distinguishes the multilaminar structure of the zona pellucida of living human eggs and embryos. Fertil. Steril. 2004; 81:850-856.
Rama Raju GA et al. Meiotic spindle and zona pellucida characteristics as predictors of embryonic development: a preliminary study using PolScope imaging. Reprod. BioMed. Online. 2007; 14:166-174.

Rienzi L et al. Significance of metaphase II human oocyte morphology on ICSI outcome. Fertil. Steril. 2008; 90:1692-1700.

Rienzi L, Vajta G, Ubaldi F. Predictive value of oocyte morphology in human IVF: a systematic review of the literature. Hum Reprod. 2010; 00:1-12.

Setti AS et al. Relationship Betwewn Oocyte Abnormal Morphology and Intracytoplasmic Sperm Injection Outcomes: A Meta-Analysis. EJOG. 2011; 159:364-370.

Shen $\mathrm{Y}$ et al. High magnitude of light retardance by the zona pellucida is associated with conception cycle. Hum Reprod. 2005; 20:1596-1606.

Silva CP et al. Effect of in vitro culture of mammalian embryos on the architecture of the zona pellucida. Biol. Bull. 1997; 193:235-236. 